\title{
Grey Relational Analysis on the development of high-tech industry and patent resources allocation in Jiangsu Province
}

\author{
Rong $\mathrm{Xu}^{1, \mathrm{a},{ }^{*},}$ Guojin Wang ${ }^{2}$
}

\author{
${ }^{1}$ School of Economics and Management, Jiangsu University of Science and Technology, Zhenjiang \\ City of Jiangsu Province 212003, China \\ ${ }^{2}$ School of Economics and Management, Jiangsu University of Science and Technology, Zhenjiang \\ City of Jiangsu Province 212003, China \\ acaiwuxr11@126.com
}

Keywords: high-tech industry; patent resource allocation; grey relation analysis; evaluation index system

\begin{abstract}
With high-tech industry of Jiangsu Province as the research object, this research established an index system from the perspective of development index of high-tech industry and input index and output index of patent resources and carried out a grey relation analysis of the relevance between development of high-tech industry and patent resource allocation. The research results showed that patent resources affect input and output efficiency of production factors through input and output configuration and then affect the development of high-tech industry. Where, patent resource input index and development of high-tech industry of Jiangsu Province had a higher relevance level, which was an important influence factor of industrial development; while patent resource output index and industrial development had a lower relevance level. This research lays a foundation for high-tech industry of Jiangsu Province to optimize allocation of patent resources and improve efficiency of patent resource allocation.
\end{abstract}

\section{Introduction}

High-tech industry is a strategy forerunner industry of national economy which plays an important role in optimization and adjustment of industrial structure and transformation of economic growth pattern. Development of high-tech industry is a key factor determining comprehensive strength and competitiveness of a country or a region ${ }^{[1]}$. Rapid development of high-tech industry is an important safeguard for realizing sustainable, stable and healthy development of china's economy and plays a ground-breaking leading role in economic growth ${ }^{[2]}$.

\section{Literature Review on Researches}

As the government attaches an increasingly higher importance to the development of high-tech industry, academic researches on this field have been continuously enriched. According to existing literature, plenty of analysis and researches have been carried out for high-tech industry from the perspective of industry innovation evaluation. Quanbao Chen and Rui Nie studied innovation ability

\footnotetext{
* Fund Project: Jiangsu province soft science project "South of Jiangsu National Independent Innovation Demonstration Zone intellectual property rights and strategic emerging industries matching relationship research" (BR2016025)

About the author: Rong Xu (November, 1991), female, Master Degree Candidate, Yancheng City of Jiangsu Province, School of Economics and Management, Jiangsu University of Science and Technology, research direction: knowledge management, technical innovation; Guojin Wang (November, 1962), male, Double bachelor's Degree, professor, Jintan City of Jiangsu Province, School of Economics and Management, Jiangsu University of Science and Technology, research direction: knowledge management, technical innovation.
} 
of high-tech industry with global principal component analysis (GPCA) and drew a conclusion that sub-industries of high-tech industry were different in the development technological innovative ability $^{[3]}$. Dahong Gao (2010) ranked indexes which affected innovation output of high-tech industry and 5 sub-industries with grey relation analysis and panel data from the perspective of innovation input and output and carried out a qualitative analysis of key influence factors of technical innovation output of high-tech industry ${ }^{[4]}$.

From the point of R\&D efficiency of high-tech industry, researches focused on efficacy of a single scientific and technological resource. For example, Ling Wang and Adam Szirmai et al (2008) analyzed innovation ability of high-tech industry based on the relation between Research input and production efficiency ${ }^{[5]}$. Such researches were just intended to cognize the contribution degree of research input or resource factors, not only research input but also other scientific and technological resources such as the number of scientific research institutions and patent were needed for promoting the development of high-tech industry.

Some scholars also analyzed the development of high-tech industry from the perspective of allocation of scientific and technological resources. For example, Langfeng Wang and Yulin Fu (2013) combined allocation of scientific and technological resources and development of high-tech industry through stochastic frontier model, carried out an empirical analysis of influences of a few important scientific and technological resources as well as relevant systems and policies upon the development of high-tech industry, and figured out difference and periodicity of such influences ${ }^{[6]}$.

In conclusion, extensive studies have been carried out for high-tech development, existing researches focus on innovation evaluation and resource input and output efficiency of high-tech industry as well as influences of scientific and technological resources upon innovation ability of high-tech industry. Besides, most researches on resource allocation are aimed at evaluating the development level of high-tech industry from the perspective of scientific and technological resources and innovation resources, but only a few focuses on the development of high-tech industry from the perspective of patent resource allocation. Based on this, relevance between input and output of patent resources and development of high-tech industry was evaluated with quantitative analysis method from the perspective of patent resource allocation in this research.

\section{Grey Relation Theory Basis}

The basic thought of grey relation system is to judge close connection between different series according to the similarity degree of series curve geometry, that is, the closer the curve is, the higher the relevance between series is, vice versa. Gray relation analysis method makes up for the deficiencies of large sample requirements of regression analysis and other methods, it can measure the relation correlation between factors according to the development trend, thus, it has not too many requirements of the sample size but can reveal the degree of features in relation to dynamics through quantitative analysis ${ }^{[7]}$.

Grey relation degree features a lower requirement of sample size and a small calculated quantity, this research has a small sample size and meets the need of grey system for database. Thus, it is more reasonable to use grey relation analysis method in this research.

Steps of grey relation analysis are as follows:

Step 1: confirm the reference series

$$
X_{o}=\left\{X_{o}(1), X_{o}(2), \ldots, X_{o}(n)\right\}
$$

Step 2: confirm the comparative series

$$
X_{i}=\left\{X_{i}(1), X_{i}(2), \ldots, X_{i}(n)\right\}, \quad i=1,2, \ldots, \quad m
$$


Initial data preprocessing. Considering inconsistent data dimensions, influences of original index unit and dimension upon index selection can be eliminated through standardized treatment of original data and translating it into a number in $[0,1]$. Initial value method and mean value method are commonly used. Initial value method is used in this research, that is, each series divides the first number and a new series will be obtained ${ }^{[4]}$, namely:

As for bigger and better indexes:

$$
X_{i}=\frac{X_{i}(K)-\min _{k}\left[X_{i}(k)\right]}{\max _{k}\left[X_{i}(k)\right]-\min _{k}\left[X_{i}(k)\right]}, \quad i=0,1,2, \ldots, m ; k=1,2 \ldots n
$$

As for smaller and better indexes:

$$
X_{i}=\frac{\max _{k}\left[X_{i}(k)\right]-X_{i}(k)}{\max _{k}\left[X_{i}(k)\right]-\min _{k}\left[X_{i}(k)\right]}, \quad i=0,1,2, \ldots, m ; k=1,2, \ldots, n
$$

Where, $X_{i}$ is the normalized index value

Step 3: calculate the correlation coefficient. Suppose the correlation coefficient between comparative series $X_{i}$ and reference series $X_{O}$ is $\xi_{o i}(k)$, the grey relational coefficient $\rho$ is generally 0.5 , the equation is shown below:

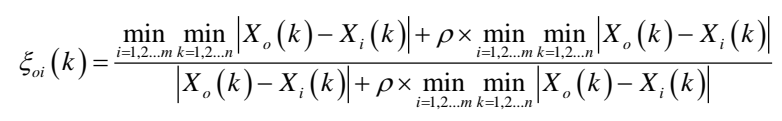

Step 4: calculate the relevance. Supper the relevance between comparative series and reference series is $\gamma_{o i}$, which reflects a stronger index of similarity and proximity of series, the relevance is figured out using equation (6):

$$
\gamma_{o i}=\frac{1}{n} \sum_{k=1}^{n} \xi_{i}(k) \quad i=0,1,2, \ldots, m
$$

Step 5: rank the relevance. Rank the relevance according to the degree and on this basis judge the relevance degree between comparative series and reference series as well as the influence degree of comparative series upon reference series.

\section{Research Design}

4.1Research Object With high-tech industry of Jiangsu Province as an example, the gray correlation between high-tech industry and 5 sub-industries and patent resource allocation was analyzed in this research.

4.2Index Design and Data Source Patent resources affect the development of high-tech industry through adjusting changes in output efficiency of production factors, while variation of patent resource allocation changes the combining form of capital and labor resource. Therefore, a set of scientific and reasonable evaluation system is needed for evaluation the development ability of high-tech industry, and selection of indexes has certain effects on scientificity and reasonability of the evaluation results. This research, through referencing to an evaluation system of high-tech industry development level established by many scholars and considering acquisition of index data, selected 8 indexes as follows (Table 1) ${ }^{[4]-[6] \text { : }}$ 
Table 1 High-tech industry development evaluation indexes

\begin{tabular}{|c|c|c|}
\hline Primary index & $\begin{array}{l}\text { Secondary } \\
\text { index }\end{array}$ & Description \\
\hline \multirow{4}{*}{$\begin{array}{l}\text { Patent resource } \\
\text { input index }\end{array}$} & $\begin{array}{l}\text { Number of } \\
\text { scientific research } \\
\text { institutions }\end{array}$ & $\begin{array}{l}\text { Reflect number of scientific research institutions, popularity } \\
\text { of scientific and technological activities and input of patent } \\
\text { resources }\end{array}$ \\
\hline & $\begin{array}{l}\text { Input intensity of } \\
\text { new product } \\
\text { development } \\
\text { expenses }\end{array}$ & $\begin{array}{l}=\text { new product development expenses/ main business income, } \\
\text { reflect input intensity of new product development expenses }\end{array}$ \\
\hline & $\begin{array}{l}\text { Input intensity of } \\
\text { R\&D expenses }\end{array}$ & $\begin{array}{l}=\mathrm{R} \& \mathrm{D} \text { expenses/main business income, reflect input } \\
\text { intensity of } \mathrm{R} \& \mathrm{D} \text { expenses and input intensity of patented } \\
\text { technologies }\end{array}$ \\
\hline & $\begin{array}{l}\text { Technology } \\
\text { introduction } \\
\text { expenses }\end{array}$ & $\begin{array}{l}\text { Reflect input intensity of patented technology introduction } \\
\text { of high-tech industry }\end{array}$ \\
\hline \multirow{3}{*}{$\begin{array}{l}\text { Patent resource } \\
\text { output index }\end{array}$} & $\begin{array}{l}\text { Patent application } \\
\text { number }\end{array}$ & Reflect patent number of high-tech industry \\
\hline & $\begin{array}{l}\text { Patent for } \\
\text { invention }\end{array}$ & Reflect proportion of patent \\
\hline & $\begin{array}{l}\text { Number of } \\
\text { effective patents } \\
\text { for invention }\end{array}$ & Reflect quality of patents of high-tech industry \\
\hline $\begin{array}{l}\text { Industrial } \\
\text { development } \\
\text { index }\end{array}$ & $\begin{array}{l}\text { Sales quota of } \\
\text { new products }\end{array}$ & $\begin{array}{l}\text { =sales revenue of new products /main business income, } \\
\text { reflect patent transformation effect, transformation effect of } \\
\text { knowledge technology into productivity, as well as } \\
\text { innovation ability and development ability of industry }\end{array}$ \\
\hline
\end{tabular}

This research selected statistics yearbooks of 2006-2015 from China Statistics Yearbook on High Technology Industry and analyzed data of high-tech industry and sub-industries of Jiangsu Province. Development index of high-tech industry was used as the dependent variable reference series, namely the parent series, input index and output index of patent resources were used as the independent variable comparative series, namely the sub-series.

4.3Data Processing According to the above model, the integrated relevance between the parent series and the sub-series is figured out using grey relation software and related data, and consequently the grey relational degree table of patent resource allocation is obtained (Table 2): 
Table 2 Grey relation degree of development of high-tech industry and sub-industry and patent resource allocation

\begin{tabular}{|c|c|c|c|c|c|c|c|}
\hline & $\begin{array}{c}\text { Patent } \\
\text { application } \\
\text { number }\end{array}$ & $\begin{array}{l}\text { Number of } \\
\text { effective } \\
\text { patents for } \\
\text { invention }\end{array}$ & $\begin{array}{c}\text { Patent } \\
\text { for } \\
\text { invention }\end{array}$ & $\begin{array}{l}\text { Number of } \\
\text { scientific } \\
\text { research } \\
\text { institutions }\end{array}$ & $\begin{array}{l}\text { New product } \\
\text { development } \\
\text { input ratio }\end{array}$ & $\begin{array}{l}\text { R\&D } \\
\text { funds } \\
\text { input } \\
\text { intensity }\end{array}$ & $\begin{array}{c}\text { Technology } \\
\text { import } \\
\text { expenses }\end{array}$ \\
\hline High-tech industry & 0.5213 & 0.5165 & 0.5262 & 0.5373 & 0.6194 & 0.7185 & 0.5564 \\
\hline Ranking & 7 & 6 & 5 & 4 & 2 & 1 & 3 \\
\hline $\begin{array}{c}\text { Pharmaceutical } \\
\text { industry }\end{array}$ & 0.5109 & 0.5073 & 0.5124 & 0.5145 & 0.7596 & 0.7521 & 0.5420 \\
\hline Ranking & 6 & 7 & 5 & 4 & 1 & 2 & 3 \\
\hline $\begin{array}{l}\text { Aerospace vehicle } \\
\text { manufacturing } \\
\text { industry }\end{array}$ & 0.5016 & 0.5055 & 0.5082 & 0.5653 & 0.8861 & 0.8398 & 0.5754 \\
\hline Ranking & 7 & 6 & 5 & 4 & 1 & 2 & 3 \\
\hline
\end{tabular}

Electronic and

telecommunications

$\begin{array}{llllllll}\text { equipment } & 0.5118 & 0.5058 & 0.5096 & 0.5144 & 0.8410 & 0.8398 & 0.6563\end{array}$

manufacturing

industry

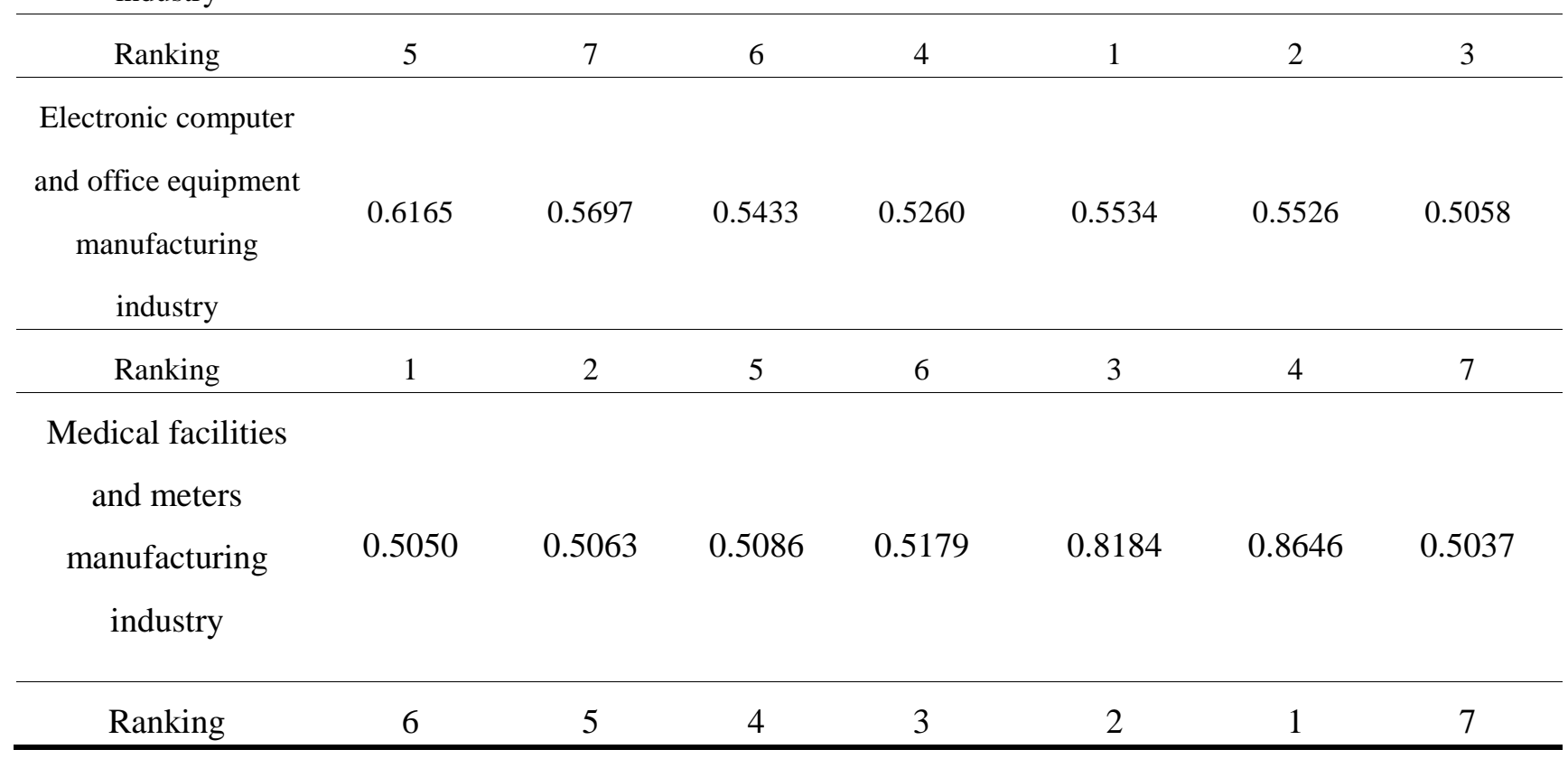

4.4Result Analysis The above grey relation degree table shows that: 1) From the point of high-tech industry of Jiangsu Province, R\&D expense input intensity has the highest relevance with industrial development and output and reflects knowledge-intensive characteristic. Development of high-tech industry should pay more attention to basic input of patent resources. While R\&D activity is the most innovative part of patent resource input activities, insufficient R\&D input intensity will affect 
the output efficiency. Nevertheless, patent application number and patent number have the highest relevance, indicating that this industry has a higher use degree of patent output resources. 2) Technology introduction is ranked at the first position in the high-tech industry, but it holds a medium position in other sub-industries, except electronic computer and office equipment manufacturing industry as well as medical facilities and meters manufacturing industry. It indicates that Chinese high-tech industry not only sticks to self-dependent innovation and enhances allocation of basic patent resources, but also values introduction of advanced patented technologies highly. However, introduction of patented technologies lacks input in electronic computer and office equipment manufacturing industry as well as medical facilities and meters manufacturing industry, and patent resources require further input. 3) New product development input ratio is ranked at the second position in the high-tech industry, it has the highest relevance in the pharmaceutical industry, indicating that new product development input is an important influence factor for the development of the pharmaceutical industry. Whereas development capability and innovation value of new products reflect the development potential of high-tech industry and patent resource is an important influence factor of new product innovation value, the correlation between input and output of patent resource allocation affects the development of high-tech industry. 4) Output index of patent resources holds a lower position in the high-tech industry, but it has the highest relevance in electronic computer and office equipment manufacturing industry. The need for basic patent resources appears very important because this industry focuses on processing and manufacturing.

\section{Conclusions}

Based on existing research findings, this research established an evaluation index system consisting of patent resource input, patent resource output and industrial development for the development level of high-tech industry of Jiangsu Province, studied the relevance between development of high-tech industry of Jiangsu Province and patent resource allocation with grey relation analysis method, analyzed the relation between industrial development and patent resource input and output, excavated major influence factors of industrial development and optimized allocation of patent resources. High-tech industry of Jiangsu Province should allocate patent resources according to the output efficiency of production factors instead of intensifying patent resource input in the patent resource allocation process.

\section{References}

[1] Wei Chen, Fuyang Zhao et al. R\&D performance evaluation research of high-tech industry based on two-stage DEA[J]. Soft Science, 2010(4): 6-10.

[2] Yulin Zhao, Fang Wei. Empirical analysis of leading role of high-tech industry development in economic growth[J]. Quantitative \& Technical Economics, 2006(6):44-54.

[3] Jinbao Chen, Rui Nie. Evolutionary analysis of technological innovative ability of high-tech industry based on GPCA[J]. Journal of China Mining University, 2005, 34(1):117-122.

[4] Dahong Gao. Analysis of high-tech industry innovative ability based on grey relation [J]. Science and Technology Management Research, 2010(16):8-11+15.

[5] Ling Wang, Adam Szirmai. Research on relationship between high-tech industry technical input and productivity growth[J]. Economics (Quarterly), 2008, 17(13):913-932.

[6] Langfeng Wang, Yulin Fu. Research on scientific and technological resources allocation of high-tech industry development[J]. Scientific Research Management, 2013, 02:152-160.

[7] Hongyan Yao, Qugui Zhu. Grey relation analysis of equipment manufacturing industry of Shanghai City and national economy[J]. Statistics and Decision,2006(8):63-64. 